\title{
Population Distribution of Wild Radish (Raphanus Raphanistrum L.) Weed and Soil Depth of Seed Bank Across Different Land-Use Types in Horro District, Western Oromia, Ethiopia
}

Geleta Shone

Wollega University

Fikiru Wakoya ( $\sim$ b.wakwoya@gmail.com )

Wollega University

Zerihun Jaleta

Wollega University

Hirpha Legese

Wollega University

\section{Research Article}

Keywords: Land use, seed bank, soil depth, weed population. wild radish, distribution

Posted Date: June 23rd, 2021

DOI: https://doi.org/10.21203/rs.3.rs-629597/v1

License: (c) (1) This work is licensed under a Creative Commons Attribution 4.0 International License.

Read Full License 


\section{Abstract}

Background: Wild radish (Raphanus raphanistrum L.) is an invasive weed in Ethiopia and hurting different land use types in the Horro district of the study area and fact, more research has not been done yet on the weed is highly infested and persisted for three decades. Therefore, this study was conducted to assess the weeds flora and seed bank status across different land use types in the Horro district of western Oromia, Ethiopia. Three locations and from each location five different land use were purposively selected and a $1 \mathrm{~m}^{2}$ area of quadratic sampling techniques was used to record weed flora. From each quadrat, soil samples were taken having two soil depth levels $(0-15 \mathrm{~cm}$ and $>15-30 \mathrm{~cm})$ to evaluate the soil seed bank of weeds.

Results: The data of wild radish weed in different location and different land use types both field survey and greenhouse experiments were found a statistically significant difference $(p<0.05)$ among the target action of land use types but there was found no significant difference among soil depths. More all less, the highest wild radish population was recorded from grazing land land followed by wheat crop land and among the locations, Gitilo Dale has the highest weed density. Among the weed flora, again wild radish was highly dominated weed species than the other weed species in all land use types and locations. From soil seed bank status of soil depth, high weed population was recorded at $0-16 \mathrm{~cm}$ of second season weed emergence from pot and Gitilo Dale was the highest infected location at this season, while barley crop land was the highest infected among land use types in first season of weed emergence from pot. Among the weed species were recorded from soil depth, again wild radish was highly dominated in both seasons. The population of weed flora per quadrat was directly proportion with population recorded from soil depth that emerged from pot.

Conclusions: This study has highly verified that this area has highly infected by wald radish (Raphanus raphanistrum) and there could be a source of weed seed. Generally, the concerned bodies should have to be given attention which should need immediate intervention strategies to mitigate the negative impacts of weed otherwise the area will be out of production soon. Therefore, an extensive integrated weed management strategies should be applied in all phases of cropping systems to sustain environment and reduce this weed in the future.

\section{Background}

Wild radish (Raphanus raphanistrum $\mathrm{L}$.) is one of the most widespread and competitive weeds in the world and has successfully occupied a variety of locations and within a short time, its colonization has reached over the world $[16,28]$. For instance, its distribution has been reported in the cropping areas of Queensland, South Wales, South Austria, and Western Austria [26, 7], and the species are also found in the Americas, Australia, Africa and Asia [5].

Wild radish grows over a wide range of ecological zone and this destructive colonizing performance might be a result of a new combination of parental traits or genetic variability of the population $[24,14]$. 
Wild radish has a strong taproot over one meter deep allowing it to survive periods of moisture stress and regrow following when slashing or grazing due to root reserves and up to $70 \%$ of the wild radish seed bank is dormant at the start of the winter cropping season and it can cause a yield loss of $10-90 \%$ in cereals and pulses $[10,31]$.

It has been expected that this weed had been introduced to Ethiopia between 1930-1935 through Italy armed forces and is now causing a serious problem on crop and range land in the Horro district of western Oromia, Ethiopia, so far, there has been no concrete evidence on how wild radish introduced into Ethiopia. A report indicates that it became a serious weed of crop and range lands in West Shewa, particularly in Welmera and Chaliya, Southwest Shewa (Waliso), and in Horro Guduru Wollega Zone western Oromia region [2].

Horro district could be considered as the area where the weed has widely distributed and cause yield up to $28.9 \%$ grain yield loss [2], however, there has not been given evidence information regarding the current status of wild radish across different land use types and soil seed bank. This research has given a piece of basic information for strategic management practices of weed especially on integrated weed management program Therefore, this research was conducted with the objective; to assess the population and soil seed bank status of wild radish weeds across different land use types in Horro district, western Oromia, Ethiopia.

\section{Materials And Methods}

\section{Study area}

The study was conducted in Horro district, Oromia Regional State, and the Western part of Ethiopia. The location is found at $9^{\circ} 33 \cdot 58^{\prime} \mathrm{N}$ Latitude and $37^{\circ} 5 \cdot 19^{\prime} \mathrm{E}$ longitude and $314 \mathrm{~km}$ distance from Addis Ababa to the western direction of Ethiopia. The district has three agroecological categories; highland (49.9\%), mid-high land (48.96\%), and low land (1.24\%) and the district receives an average annual rainfall of $2000 \mathrm{~mm}$, temperature $8-32^{\circ} \mathrm{C}$ and altitude 1350 - $3170 \mathrm{~m}$ a.s.I. (Horro Guduru Zone, Agricultural and Natural Resource 2018 unpublished).

\section{Sampling procedures and experimental design}

The study was conducted in 2018 growing season in three locations (Lakku Iggu, Doyo Bariso, and Gitilo Dale) of Horro district, Oromia state, western Ethiopia and from each location, five land use types (wheat land, teff land, barley land, grazing land, and forest land) were purposely selected based on weed boundary, weed association, weed density, and distribution because reported that a wide variety of field survey has to be confirmed that cause-effect dealings can be checked for generality [19]. For the floras survey, a $1 \mathrm{~m}^{2}$ area of quadrat was used randomly to assess the seedling population density of weed from each land use type [8]. Systematic sampling approach was used for soil sample having 0 $15 \mathrm{~cm}$ and $16-30 \mathrm{~cm}$ soil depth to assess the status of the weed seed bank in greenhouse experiment and 
$20 \mathrm{~cm}$ diameter pots was used to grow weed in a greenhouse $[8,1]$. The treatments were arranged in a randomized complete block design (RCBD) with three replications.

\section{Data collection}

Weed flora was collected by direct counting of plant species in the habitats and quantitative analysis of weed population and relative weed density were competed according to the authors of the following formula [20, 17].

Relative density $=\frac{\text { total number of targated weed species }}{\text { total number of all weed species }} * 100$

Population density $=\frac{\text { total number of wild radish weed in all quadrants }}{\text { Total number of quadrants in which all weed species occurred }}$

\section{Data analysis}

Data were subjected to analysis of variance (ANOVA) with SAS computer software version 9.4 [29] and descriptive statistics were used to explain the average weed species population. Means of wild radish populations were compared with the least significance difference (LSD) at a $5 \%$ probability level.

\section{Results}

\section{Wild radish population}

Mostly, this study was given as a clue about wild radish and other weed species and wild radish weed has the leading species in Horro district, western Oromia, Ethiopia. Correspondingly about five weed species were recorded and well-identified from the area. The analysis of variance (ANOVA) indicated that the main effect of land use types and locations on wild radish was a highly significant difference $(\mathrm{P}<$ 0.001) among the treatments, however, the interaction of land use types and locations were found a nonsignificant difference $(P<0.001)$ among the treatments (Table 1). From land use types, grazing land was more dominated by wild radish (276 (1.99) followed by wheat crop land 237 (1.96). From the locations, Gitilo Dale was more dominated by weed 253 (1.94) followed by Doyo Bariso location 149 (1.83), and Lakku Iggu was relatively less persisted by weed (Table 1 ).

Table 1 The main effect of land use and locations for wild radish weed population 


\begin{tabular}{ll} 
Treatment & Wild radish population \\
\hline Land use types & \\
\hline Grazing land & $276(1.99)^{\mathrm{a}}$ \\
\hline Forest Land & $90(1.74)^{\mathrm{b}}$ \\
\hline Wheat crop land & $237(1.96)^{\mathrm{a}}$ \\
\hline Barley crop land & $150(1.81)^{\mathrm{ab}}$ \\
\hline Teff crop land & $71(1.69)^{\mathrm{b}}$ \\
\hline LSD (5\%) & 84.90 \\
\hline Location & \\
\hline Gitilo Dale & $253(1.94)^{\mathrm{a}}$ \\
\hline Lakku Iggu $^{\mathrm{a}}$ & $94(1.75)^{\mathrm{b}}$ \\
\hline Doyo Bariso & $149(1.83)^{\mathrm{b}}$ \\
\hline LSD (\%) & 65.80 \\
\hline Land use type* location & \\
\hline LSD (\%) & $\mathrm{NS}$ \\
\hline CV (\%) & 4.70 \\
\hline
\end{tabular}

Means followed by the same letter(s) within rows are not significantly different at $P \leq 0.05$ level of significance, The figures in the parenthesis are the transformed values for wild radish count from the quadrant.

\section{The population of weed species}

This survey result shows as high population density and relative density were estimated on Raphanus raphanistrum in all land use types followed by Digiteria abyssinia. However, a little bit there was a difference in Barley crop land, and the second-highest weed population was estimated from Avena fatua and Plantago lanceolata weed species from Teff crop land (Table 2).

Table 2 The relative weed density and population of weed flora for each land uses types 


\begin{tabular}{|c|c|c|c|}
\hline Land use types & Scientific Name & Weed Population & RWD \\
\hline Forest land & Raphanus raphanistrum & 90 & 47.37 \\
\hline Guizotia scabra & 14 & 7.37 & \\
\hline Digiteria abysinica & 34 & 9.69 & \\
\hline Cyperus rotundus & 31 & 16.32 & \\
\hline Galinsoga paniyflora & 9 & 4.74 & \\
\hline Other weeds & 4 & 2.11 & \\
\hline Grazing Land & Raphanus raphanistrum & 276 & 78.63 \\
\hline Guizotia scabra & 19 & 5.41 & \\
\hline Digiteria abysinica & 42 & 22.11 & \\
\hline Cyperus rotundus & 13 & 3.7 & \\
\hline Galinsoga paniyflora & 7 & 1.99 & \\
\hline Other weeds & 2 & 0.57 & \\
\hline Wheat crop & Raphanus raphanistrum & 237 & 73.6 \\
\hline Guizotia Scabra & 27 & 8.39 & \\
\hline Digiteria abysinica & 28 & 8.7 & \\
\hline Avena fatua & 23 & 7.14 & \\
\hline Galinsoga paniyflora & 4 & 1.24 & \\
\hline Other weeds & 3 & 0.93 & \\
\hline Barley crop & Raphanus raphanistrum & 150 & 64.38 \\
\hline Guizotia scabra & 11 & 4.72 & \\
\hline Digiteria abysinica & 18 & 7.73 & \\
\hline Avena fatua & 37 & 15.88 & \\
\hline Galinsoga paniyflora & 12 & 5.15 & \\
\hline Other weeds & 5 & 2.15 & \\
\hline Teff crop & Raphanus raphanistrum & 71 & 47.02 \\
\hline Guizotia scabra & 24 & 15.89 & \\
\hline Digiteria abysinica & 15 & 9.93 & \\
\hline Plantago lanceolata & 30 & 20.53 & \\
\hline
\end{tabular}


Galinsoga paniyflora 8

Other weeds
2
5.3

1.32

A high population of Raphanus raphanistrum weed species was recorded in Gitilo Dale (253) location followed by Digiteria abysinica (117) whereas the lowest was recorded in Doyo Bariso (149) and Lakku (94) followed by Digiteria abysinica 111 and 60 respectively in both locations and from all locations, Galinsoga paniyflora species was recorded in the least population density (Table 3).

Table 3 The relative weed density and population of weed flora for each location

\begin{tabular}{llll} 
Location & Scientific Name & Weed Population & RWD \\
\hline Gitilo Dale & Raphanus raphanistrum & 253 & 44.39 \\
\hline Digiteria abysinica & 117 & 20.53 & \\
\hline Avena fatua & 114 & 20.00 & \\
\hline Pilantago lanceolata & 62 & 10.88 & \\
\hline Galinsoga paniyflora & 21 & 3.68 & 42.53 \\
\hline Other weeds & 3 & 0.53 & \\
\hline Doyo Bariso & Raphanus raphanistrum & 149 & \\
\hline Digiteria abysinica & 111 & 26.75 & \\
\hline Avena fatua L. & 78 & 18.8 & \\
\hline Pilantago lanceolata & 58 & 13.98 & \\
\hline Galinsoga paniyflora & 18 & 4.34 & \\
\hline Other weeds & 1 & 0.24 & \\
\hline Lakku lggu & Raphanus raphanistrum & 94 & \\
\hline Digiteria abysinica & 60 & 27.15 & 14.48 \\
\hline Avena fatua L. & 32 & 9.95 & 4.52 \\
\hline Pilantago lanceolata & 22 & 10 &
\end{tabular}

\section{Soil seed bank evaluation}

The analysis of variance (ANOVA) indicated that the main effect of land use types was found a significant difference $(P<0.001)$ on the first and second season of wild radish emerged from pot. However, regarding weed species composition, there was found a non- significant difference $(P<0.001)$ on the first and second season of weed flora emerged from the pot, and the main effect of soil depth also was found non-significant difference on all variables. The main effect of locations was found significant 
difference on the second season of wild radish emerged from the pot and species composition of weed flora of first season variables, however, there was found non-significant difference on the first season of wild radish emerged from the pot and species composition of weed flora of second season variables. In all interactions, it was found a non- significant difference in all variables (Table 4). A maximum number of wild radish population was recorded from Barley crop land of both first and second season grown in a pot. However, for weed flora of weed species composition, grazing land, and forest land have led to both the first and second season of weed emergence. The same phenomenon, maximum population of wild radish was emerged from $16-30 \mathrm{~cm}$ soil depth than $0-15 \mathrm{~cm}$ soil depth in both seasons, however, for weed species maximum number of weed flora was recorded from $0-15 \mathrm{~cm}$ soil depth (Table 4 ).

Table 4 The main effect of Land use, soil depth, and locations on the emergence of weed flora 
Treatment

Land use types

Grazing land

Forest Land

wheat land

Barley land

Teff land

$\operatorname{LSD}(5 \%)$

Soil depth

$0-15 \mathrm{~cm}$

$16-30 \mathrm{~cm}$

LSD (\%)

Location

Gitilo Dale

Lakku Iggu

Doyo Bariso

LSD (\%)

Land use* location

LSD (\%)

Land use ${ }^{\star}$ Soil depth

LSD (\%)

Location * Soil depth

LSD (\%)

Land use* location* Soil depth

CV (\%)

NS

36

NS

NS

NS

NS

NS
$\operatorname{LSD}(5 \%)$

SSWEP

FSWFEP

SSWFEP

FSWEP

4.06 (1.87) b

$5.78(2.27) a b$

$5.44(2.27)$

$2.28(1.314)$

2.89 (1.472) b

5.28 (2.21) b

$5.22(2.145)$

3.61 (1.634)

$10.72(3.225)$ a $\quad 7.22(2.4) a b$

$4.11(1.864)$

3.17 (1.546)

$11.33(3.165)$ a $9.06(3) a$

$4.11(1.86)$

$1.67(1.033)$

$5.22(2.154) b \quad 7(2.59) a b$

4.17 (1.968)

$1.44(1.065)$

2.62

2.309

NS

NS

$6.76(2.32) \quad 6.4(2.38)$

$4.67(2.011)$

$2.62(1.437)$

$6.93(2.437)$

$7.33(2.6)$

$4.56(2.015)$

$2.24(1.2)$

NS

NS

NS

7.33 (2.435)

8.27 (2.76) a

$3.27(1.686) b$

2.57 (1.466)

$5.83(2.228)$

6.3 (2.33) ab

6.1 (2.3) a

2.43 (1.14)

7.37 (2.478)

6.03 (2.35) b

4.47 (1.995) ab

2.3 (1.349)

1.789

1.536

NS

NS

3.434

NS

NS

NS

NS

NS

NS

NS

Means followed by the same letter(s) within rows are not significantly different at $P \leq 0.05$ level of significance, The figures in the parenthesis are the transformed values for wild radish count from the quadrant. The figures in the parenthesis are the transformed values for wild radish count from quadrant 


\section{$1^{\text {st }}$ and $2^{\text {nd }}$ seasons evaluation}

The first season greenhouse works result indicated that about five weed species were well identified including wild radish species which was emerged from pot. As a result, a maximum number of wild radish species was germinated from a pot which has been from barley land (11) and wheat land (10) followed by Avena fatua from teff land (7), while minimum weed species, Avena fatua, and Guizotia abysinica were recorded from forest land (Table 5). It was deviated in between 0.75-3.5 ranges. From the second season germination, the maximum number of individual species was recorded on Raphanus raphanistrum (9.00) in Barley land followed by wheat land and teff land (7.00), while the minimum number of species was recorded from all land use types (Table 5).

Table 5 The relative density of weed flora emerged from pot by land use types 
Land $\quad$ Relative density of weed Species

use

types

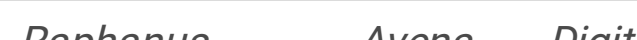

Raphanus Avena Digiteria Guizotia Cyperus Other

raphanistrum fatua sanguinalis abysinica rotundus species Total

$1^{\text {st }}$

season

\begin{tabular}{lccccccc}
$\begin{array}{l}\text { Forest } \\
\text { Land }\end{array}$ & 2.00 & 1.00 & 2.00 & 1.00 & 2.00 & 3.00 & 11.00 \\
\hline $\begin{array}{l}\text { Grazing } \\
\text { land }\end{array}$ & 4.00 & 3.00 & 3.00 & 2.00 & 3.00 & 2.00 & 17.00 \\
\hline $\begin{array}{l}\text { Wheat } \\
\text { land }\end{array}$ & 10.00 & 6.00 & 2.00 & 1.00 & 2.00 & 5.00 & 26.00 \\
\hline $\begin{array}{l}\text { Barley } \\
\text { land }\end{array}$ & 11.00 & 2.00 & 1.00 & 3.00 & 6.00 & 1.00 & 24.00 \\
\hline $\begin{array}{l}\text { Teff } \\
\text { land }\end{array}$ & 5.00 & 7.00 & 3.00 & 5.00 & 4.00 & 3.00 & 27.00 \\
\hline Total & 32.00 & 19.00 & 11.00 & 12.00 & 17.00 & 14.00 & 105.00 \\
\hline Mean & 6.40 & 3.80 & 2.20 & 2.40 & 3.40 & 2.80 & 21.00 \\
\hline SD \pm & 3.50 & 2.32 & 0.75 & 1.50 & 1.50 & 1.33 & 6.10 \\
\hline
\end{tabular}

\section{$2^{\text {nd }}$}

season

\begin{tabular}{lccccccc}
$\begin{array}{l}\text { Forest } \\
\text { Land }\end{array}$ & 5.00 & 2.00 & 1.00 & 2.00 & 3.00 & 1.00 & 14.00 \\
\hline $\begin{array}{l}\text { Grazing } \\
\text { land }\end{array}$ & 6.00 & 2.00 & 3.00 & 1.00 & 3.00 & 2.00 & 17.00 \\
$\begin{array}{l}\text { Wheat } \\
\text { land }\end{array}$ & 7.00 & 3.00 & 1.00 & 5.00 & 4.00 & 1.00 & 21.00 \\
\hline $\begin{array}{l}\text { Barley } \\
\text { land }\end{array}$ & 9.00 & 4.00 & 3.00 & 1.00 & 2.00 & 3.00 & 22.00 \\
\hline $\begin{array}{l}\text { Teff } \\
\text { land }\end{array}$ & 7.00 & 1.00 & 3.00 & 2.00 & 4.00 & 2.00 & 19.00 \\
\hline Total & 34.00 & 12.00 & 11.00 & 11.00 & 16.00 & 9.00 & 93.00 \\
\hline Mean & 6.80 & 2.40 & 2.20 & 2.20 & 3.20 & 1.80 & 18.60 \\
\hline SD \pm & 1.33 & 1.02 & 0.98 & 1.47 & 0.75 & 0.75 & 2.87 \\
\hline
\end{tabular}

The average number of Raphanus raphanistrum was compared with weed flora or weed species, wild radish was highly figured than the other weed species in location by soil depth. The number of weed flora 
from the soil seed bank has fluctuated per soil depth or there was shown not many differences between the soil depth (Fig. 2).

\section{Discussion}

Weed problems are becoming increasingly difficult to mitigate that currently, Ethiopia has faced, especially there has been at higher risk of exotic weed like wild radish as result of an increase in the travel trade and poor quarantine agency as well as by nature wild radish emergence is more aggressive and prolific before crop emergence and this may be partly responsible for its large effects on crop growth and yield loss $[10,34]$. Some authors have reported that the anthropogenic development of weed distribution and dispersal are also influenced by annual activities in the current cropping system and spatial variability in current agronomic practices within the field. Thus, the real-time approaches for the difficulty to having actual data of the study areas especially in disturbed land or cropping land use and has been reported that pending action and mapping for future attempt to take control measurements $[14,3]$.

This survey would have to be preferable to use weed density and relative weed density measurements in uniform size vegetation to avoid underestimation of individuals' which expresses the numerical strength of a target species of wild radish with the total number of individuals of all the species that occurred $[35,13]$. Wild radish is the highest number of individuals from assessed species in the community per cumulative quadrat data and it would have high overall importance of each species in the different land use types of Horro district of the study area. This study area would show as the number of individual species has estimated different figures and these differences could have because of age, growth stage, biotype or environments may affect the morphological appearance or at least particular morphological traits of the same weed species $[6,18]$.

Weed species including wild radish (Raphanus raphanistrum) with wide geographical distributions might look a strong selection to adapt to new environments and the colonization ability and persistency could be strongly influenced by the population's ability to evolutionarily adapt to new abiotic and biotic environments $[4,14,28]$, otherwise, species may be preadapted to new environmental conditions by chance [30, 23]. The altitude, soil type, temperature, and soil texture class are the factors, and this geographically differentiated weed that would have affected the distribution of weeds in the study area and quantitative floristic inventories provide a necessary context for planning and interpreting long-term ecological research [15]. The populations from the nearby location would show greater similarity than more widely separated locations, for instance, most of the time alike population of individual species has shown in Lakku Iggu location which is different from either Doyo Bariso and Gitilo Dale, which is supported by the reports has emphasis, environmentally similar sites would show greater similarity than from dissimilar sites [4].

In the Horro district especially the study area, wild radish was introduced for a long list of about more than 30 years because it is obvious, the seed dormancy assists the survival of plants in several ways; including ensuring the persistence of species in risky environments, enabling germination to agree with 
the season most favorable for plant growth and interacting with other life cycle traits in helping the plant to maintain itself [33], and it is the most persisted weed species in this area in various land use types because it is one of the most problematic and competitive $[25,2,9]$ reports. Plant attributes particularly important to weeds include adaptations for effective seed dispersal, seed dormancy, long-lived seed bank, rapid growth, and phenotypic plasticity [4]. The seed bank remains high even under the worst conditions for seed production and seeds can remain viable in the soil for 15 to 20 years $[26,18]$. There would no disturbances, because there would be fewer human activities that affected the emergence of wild radish in forest land and a little bit in grazing land, so that in one area more seeds produced from a single plant that one can have an opportunity for more seed production and more seed bank.

The primarily important aspect of this study would have that wild radish has an effective and long-lasting dormancy mechanism and it is similar to the successful exotic annual legumes, most of which have dormancy mechanisms lasting several years [4]. It is likely to achieve that Raphanus raphanistrum is a highly spreading weed causing a devastating effect on cereal crop production in the study area as compared to other weed species. The finding result supports that the cultivation leads to shallow burial of wild radish seed in moist soil enhancing germination [7]. And Cultivation enhances seedling emergence and reduces the seed bank [22]. The result shows that in barley and wheat crops land this weed has more distributed but in forest and grazing lands it has shown as the lowest distribution because those lands were not cultivated or undisturbed lands and this uncultivated land has deeper burial depth and decreases weed seed emergence. This result supports the finding of the average depth of emergence in all soil conditions up to $16 \mathrm{~cm}$ soil depth $[36,12,3]$.

When camper to the result of the evaluation of the first season and second season seed bank in the soil at different soil depth it relatively the same at the depth of soil sample in $0-15 \mathrm{~cm}$ and $16-30 \mathrm{~cm}$ because the depth not more much far from each and the soil sample is taken to analysis is the same. The difference in weed distribution might be due to the soil type and this could be affected the seed dormancy of weeds. This finding would have supported with [27] report that seed numbers in soil declined with time but the loss was much slower at $100 \mathrm{~mm}$ depth than with shallower burial [35]. A cultural weed control strategy probably, increasing crop density can suppress wild radish and reduce its population especially it would be preferable for the weed seed-bank management programs and could be an important constituent of an integrated weed management program [10].

Several information has given that recently increasing consideration to external drivers of weed distribution, including the relationship between weeds and environmental properties, as well as anthropogenic drivers of weed distributions [32]. Usually, biological and ecological procedures have designed the source of Spatio-temporal weed models with certain stress on processes such as dispersal and competition, which become predominantly appropriate when considering spatial distributions of the study area. Ecological based information is still needed for the operation of weed management and some practices may be difficult or impossible to implement in certain topographies, but knowledge and some level of certainty must be added and decision-making processes should be required for weed control and prevent crop yield losses $[19,21,11]$. Therefore, a wide range of weed management options that target all 
phases of the cropping systems and environmental manipulation is needed to sustain to reduce this weed in the future.

\section{Conclusion}

Our study demonstrates, this area has highly verified by wild radish (Raphanus raphanistrum) and there could be a source of weed seed. Subsequently, there are the marginalized area where the researchers were not given attention and farmers are strongly competing with weed by individual. Even though, Ethiopian ministry of agriculture and regional administration have tried to supply some agriculture input, still they no concretive evidence about the distribution of the wild radish weed except the local administration and farmers, that is true also they have no capacity to overcome the effects of this weed. In fact, one trips of survey would not be concluded and could not be given concrete information unless it requires wide investigation for several times over a wide range of locations. Some information has given that recently increasing consideration to outward drivers of weed distribution. Generally, the concerned bodies should have to be given attention which should need immediate intervention strategies to mitigate the negative impacts of weed otherwise the area will be out of production soon. Therefore, an extensive integrated weed management strategies should be applied in all phases of cropping systems to sustain environment and reduce this weed in the future.

\section{Abbreviations}

RWD: Relative weed density

FSWEP: First season wild radish emerged from pot

SSWEP: Second season wild radish emerged from pot

FSWFEP: First season weed flora emerged from pot

SSWFEP: Second season weed flora emerged from pot

$\mathrm{SD} \pm$ : Standard deviation (the population could deviated either to the negative or positive)

\section{Declarations}

\section{Acknowledgment}

The authors, thanks to Professor P. Gomathinayagam, Department of Plant Sciences, Wollega University, for critically commenting on the draft manuscript. The authors would like to thank Wollega University, for advising on the study. 


\section{Authors' contributions}

Gelata Shone designed the study and performed the research, Hirpha Negese and Zerihun Jaleta advised and commented the research. Fikiru Wakoya analyzed the data and drafted the manuscript, and all authors finalized it. All authors read and approved the final manuscript.

\section{Funding}

The study did not receive any external funding.

\section{Availability of data and materials}

All data generated from the field experiments and reported in the manuscript are included in the article. Further data sets are available from the corresponding author upon request.

\section{Ethics approval and consent to participate}

The data collection does not require permits in Ethiopia and not applicable to this study.

\section{Consent for publication}

Not applicable.

\section{Competing interest}

The authors declare no competing interests.

\section{Author details}

${ }^{1}$ Horro Agricultural bureau, Horro Guduru district, Western Oromia, Ethiopia

${ }^{2}$ College of Agriculture and Natural resources, Wollega University, P.O. Box 38 Shambu, Ethiopia

${ }^{3}$ Plant Protection Research Center, P. O. Box 37, Ambo, Ethiopia

\section{References}


1. Ambrosio L, Iglesias L, Mari CN, Monte JPDEL. Evaluation of sampling methods and assessment of the sample size to estimate the weed seed bank in soil , taking into account spatial variability. 2004, pp. 224-36.

2. Bedada S, Hundesa N, Gela D, Bekele G. Evaluation of integrated management of wild radish (Raphanus raphanistrum) in faba bean in Waliso district of south west. No. 5, 2020, pp. 9-17, doi:10.7176/JBAH/10-5-02.

3. Berger Z, Ecol BMC, Berger JZ, Waitz Y, Behar E, Joseph O, Ben Bezalel L, Wasserstrom H, Bajpai PK, Bhattacharya S, Przesdzink F, Westberg E, Mummenhoff K, Barazani O. Seed dispersal of wild radishes and its association with within population spatial distribution. BMC Ecology, biomed Central, 2020, pp. 1-10, doi:10.1186/s12898-020-00297-4.

4. Bhatti MALI. Genetic variation in naturalized wild radish (Raphanus raphanistrum $L$ ) populations in the Mediterranean climate of south-western Australia. June, 2004.

5. Campbell LG, Snow AA, Campbell LG. Competition alters life history and increases the relative fecundity of crop - wild radish hybrids (Raphanus Spp.). 2006, pp. 648-60.

6. Caryl LE, Daniel WS, John WW. Measuring \& Monitoring of plant populations. Bureau of Land Management National Business Center, Denver, Colorado, 2005

7. Cheam AH, Code GR. Wild radish (Raphanus raphanistrum L.): The biology of Australian weeds. 1995, Plant Protection Quarterly, 10, 2-13.

8. Colbach N, Dessaint F, Forcella F. Evaluating field-scale sampling methods for the estimation of mean plant densities of weeds. 2000, pp. 411-30.

9. Eslami SV. Ecology of wild radish (Raphanus raphanistrum) crop-weed competition and seed dormancy Seyed Vahid Eslami Thesis Submitted for the Degree of Doctor of philosophy (Phd) School of Agriculture, Food and V / Ine Faculty of Sciences The University Of. 2006.

10. Eslami SV, Gill GS, Bellotti B, Mcdonald G, Mcdonald G. Wild Radish (Raphanus Raphanistrum) interference in wheat. No. 4, 2006, pp. 749-56.

11. Gage KL, Schwartz-lazaro LM. Shifting the Paradigm: An Ecological Systems Approach to Weed Management. 2019, pp. 1-17.

12. Gardarin A, Guillemin JP, Munier-Jolain NM, Colbach N. Estimation of key parameters for weed population dynamics models: Base temperature and base water potential for germination. European Journal of Agronomy, vol. 32, no. 2, 2010, pp. 162-68, doi:10.1016/j.eja.2009.09.006.

13. Hanzlik K, Gerowitt B. Methods to conduct and analyse weed surveys in arable farming: A Review. 2016, doi:10.1007/s13593-015-0345-7.

14. Hegde SG, Nason JD, Clegg JM, Ellstrand NC. The evolution of California 's wild radish has resulted in the extinction of its progenitors the evolution of california ' $s$ wild radish has resulted in the extinction of its progenitors. No. 6, 2006, pp. 1187-97.

15. Haruna $\mathrm{H}$, Aliko AA, Zakari SM, Omeiza AH. Quantitative analysis of plant species diversity in kano zoological garden. Special Conference Edition, November, 2018. Bayero Journal of Pure and Applied Sciences, 11(1): 208 -213. http://dx.doi.org/10.4314/bajopas.v11i1.34S 
16. Holm LG, Plucknett DL, Pancho JV, Herberger JP. The world's worst weeds: distribution and biology. East-West Center, University Press of Hawaii. 609 pp. 1997.

17. Liu S, Baret F, Allard D, Jin X, Andrieu B, Burger P, Hemmerlé M, Comar A. A Method to estimate plant density and plant spacing heterogeneity: Application to wheat crops. Plant Methods, biomed Central, 2017, pp. 1-11, doi:10.1186/s13007-017-0187-1.

18. Malik M. Biology and ecology of wild radish ( Raphanus raphanistrum ). 2009.

19. Masin R, Vasileiadis VP, Loddo D, Otto S, Zanin G, Masin R, Vasileiadis VP, Loddo D, Otto S, Zanin GA. Single-time survey method to predict the daily weed density for weed control decision-making. No. 2 , 2011, pp. 270-75, doi:10.1614/WS-D-10-00148.1.

20. Maszura CM, Karim SMR, Norhafizah MZ, Kayat F, Arifullah M. Distribution, density, and abundance of Parthenium weed ( Parthenium hysterophorus L .) At Kuala Muda, Malaysia. 2018.

21. Mechelle JO, Neree JM, Stephen BP. Multiple herbicide-resistant wild radish (Raphanus raphanistrum) populations dominate western Australian cropping fields. 2015, pp. 1079-85.

22. Murphy WC, Lemerle D, Medd R, Cullis B, Road PG, Wagga W, Road F. Manipulation of wild radish emergence to accelerate seedbank decline: preliminary findings. Pp. 256-60.

23. Ngouajio M, Mansfield S, Ogbuchiekwe E. Comparison of methods to estimate weed populations and their performance in yield loss description models. No. 3, 2016, pp. 385-94.

24. Parsons WT, Cuthbertson EG. Noxious weeds of Australia. Inkarta Press, 1992, https://www.cabdirect.org/cabdirect/abstract/19922320198.

25. Powles SB, Todd AG. Exploring the potential for a regulatory change to encourage diversity in herbicide use. Weed Science 64, no. sp1 (2016): 649-654.

26. Piggin CM, Reeves TG, Brooke HD, Code GR. () Germination of wild radish (Raphanus raphanistrum). Proceeding of the 1st Conference of Australia Weed Science Society, 1978. pages 233-240.

27. Reeves TG, Code GR, Piggin CM. Seed production and longevity, seasonal emergence and phenology of wild radish (Raphanus raphanistrum L.). Australian Journal of Experimental Agriculture, vol. 21, no. 112, 1981, pp. 524-30, doi:10.1071/EA9810524.

28. Sahli HF, Conner JK, Shaw FH, Howe S, Lale A. Adaptive differentiation of quantitative traits in the globally distributed weed, wild radish (Raphanus raphanistrum). No. October, 2008, pp. 945-55, doi:10.1534/genetics.107.085084.

29. SAS/STAT User's Guide, version 9.3 for window. 2011, SAS Institute Inc., Cary

30. Shiferaw W, Demissew S, Bekele T. Invasive alien plant species in Ethiopia: Ecological impacts on biodiversity: A Review Paper. No. 4, 2018, pp. 169-76, doi:10.15406/ijmboa.2018.03.00072.

31. Storrie L, Christian L, Magnus A, Russell BW, Kit MK. Determining the species assemblage and habitat use of cetaceans in the Svalbard Archipelago, based on observations from 2002 to 2014. 2018, Polar Research, 37:1, 1463065, DOI: 10.1080/17518369.2018.1463065

32. Somerville GJ, Sønderskov M, Mathiassen SK. Spatial modelling of within field weed populations: A Review. 2020, pp. 1-18. 
33. Tavares LC, Lemes ES, Ruchel Q, Westendorff NR, Agostinetto D. Criteria for decision making and economic threshold level for wild radish in wheat crop. 2019, pp. 1-11, doi:10.1590/S010083582019370100004.

34. Tessema T. The prospects of biological control of weeds in Ethiopia. No. 1, 2007, pp. 63-78.

35. Travlos IS, Cheimona N, Roussis I, Bilalis DJ. Weed-species abundance and diversity indices in relation to tillage systems and fertilization. No. April, 2018, pp. 1-10, doi:10.3389/fenvs.2018.00011.

36. Young $\mathrm{K}$, Cousens R. Factors affecting the germination and emergence of wild radish (Raphanus Raphanistrum) and their effect on management options. Twelfth Australian Weeds Conference, 1998, pp. 179-82.

\section{Figures}

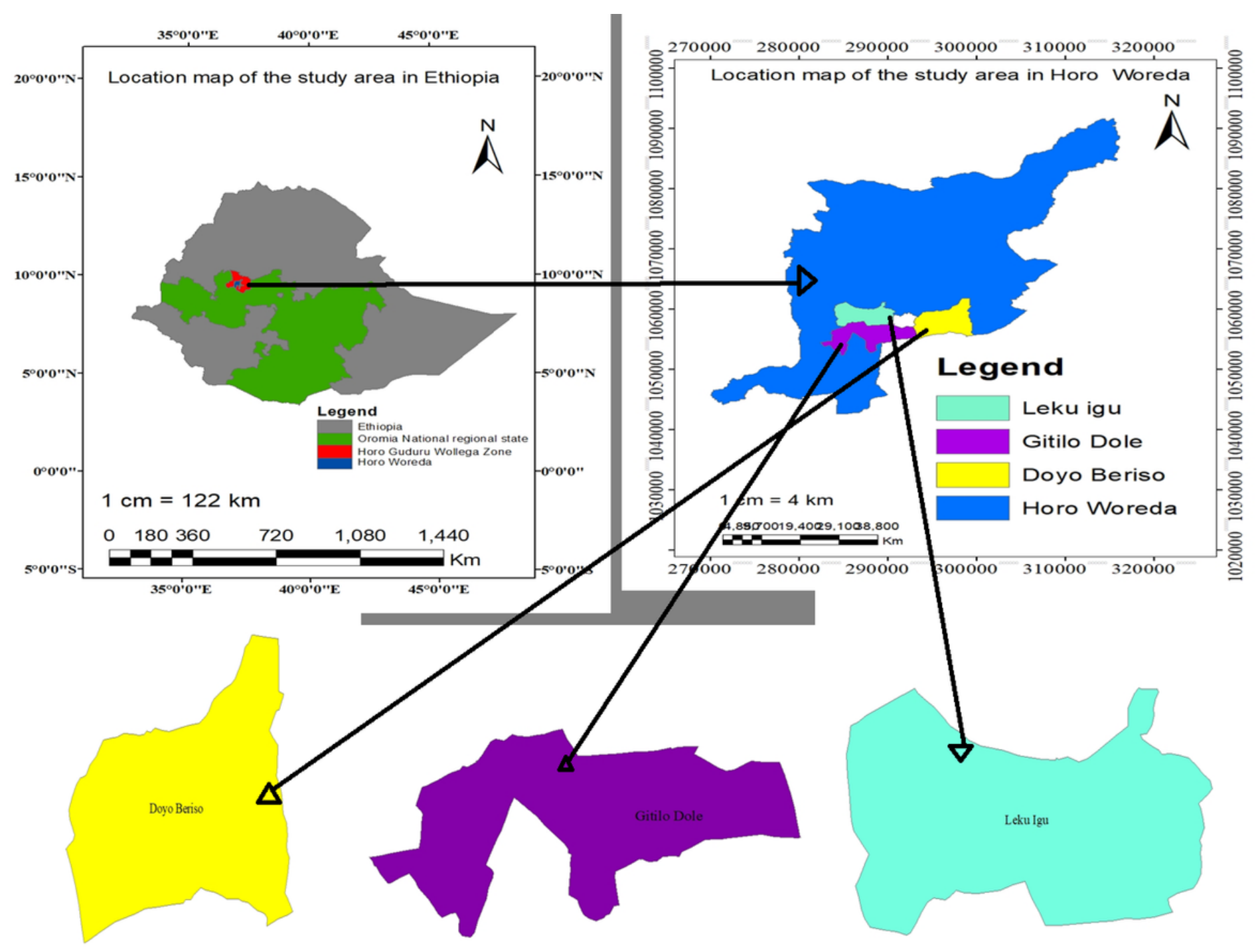

Figure 1 
Map of Ethiopia showing the Horro district and the study areas Note: The designations employed and the presentation of the material on this map do not imply the expression of any opinion whatsoever on the part of Research Square concerning the legal status of any country, territory, city or area or of its authorities, or concerning the delimitation of its frontiers or boundaries. This map has been provided by the authors.

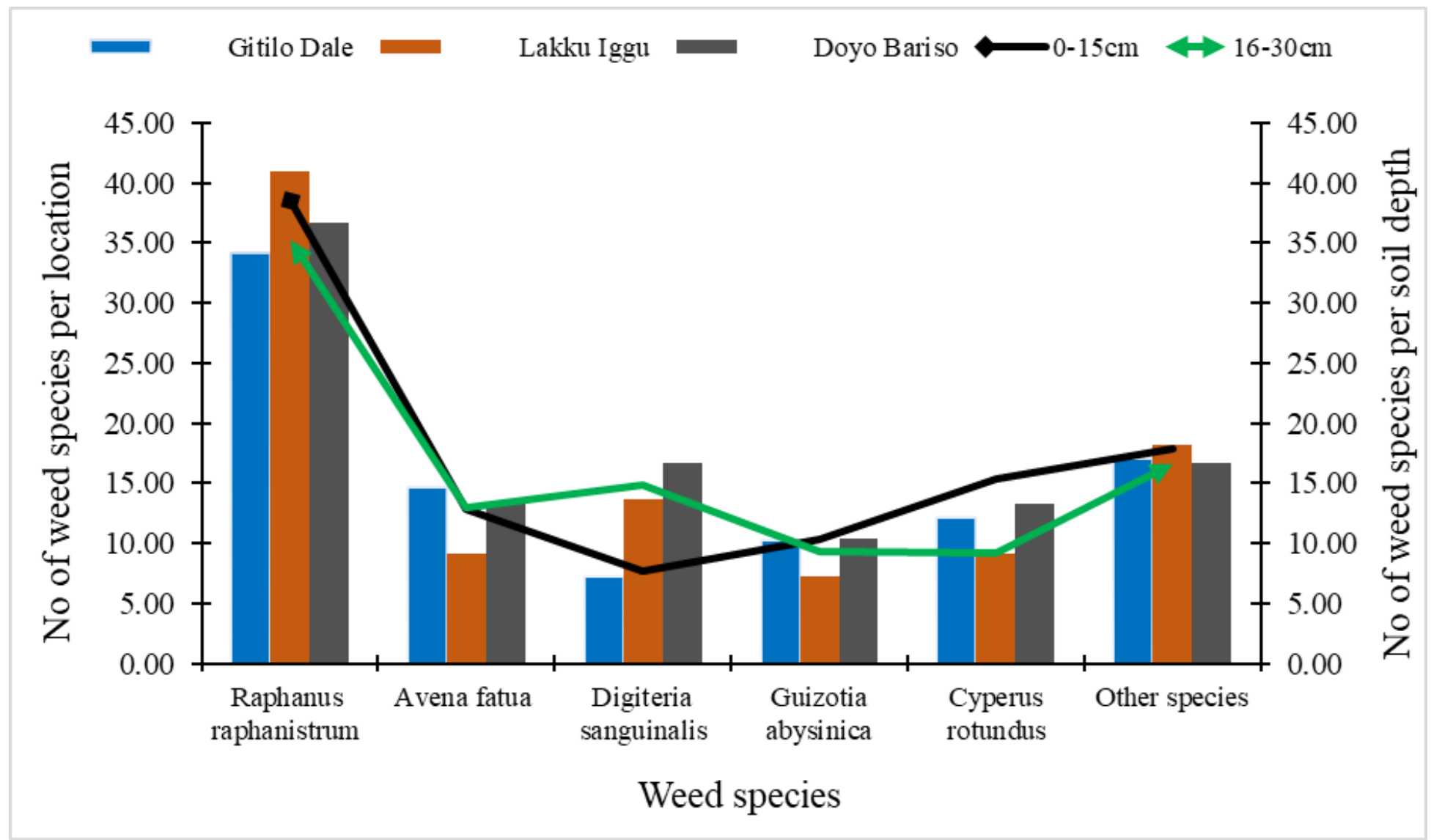

Figure 2

The average number of weed species per soil depth and location of both first and second seasons evaluation 